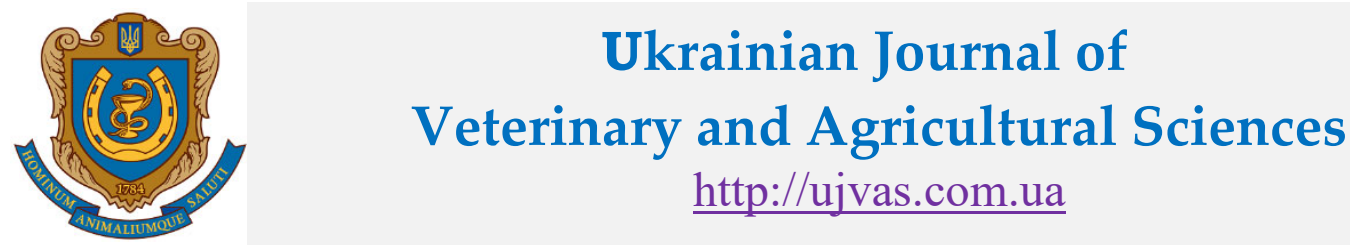

Stepan Gzhytskyi National University of Veterinary Medicine and Biotechnologies Lviv

\begin{tabular}{l|l|l} 
original article & UDC 619:615.356.2.636.7 & doi: 10.32718/ujvas3-1.01
\end{tabular}

Volume 3

Number 1

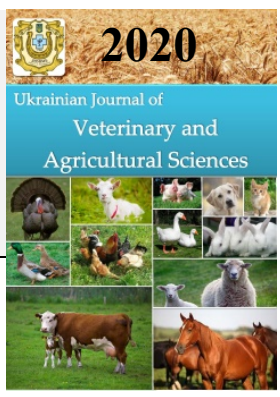

\title{
Evaluation the effect of using thyme and oregano powder in comparison to the antibiotic and probiotic supplementation on growth, some immune responses and intestinal morphology of broiler chicks
}

\author{
Omid Parvizi ${ }^{1}$, Reza Taherkhani ${ }^{2}$, Mehran Abouzari ${ }^{3}$ \\ ${ }^{I}$ Department of Animal Sciences, Islamic Azad University, Karaj Branch, Karaj, Iran \\ ${ }^{2}$ Department of Animal Sciences, Faculty of Agriculture, Payame Noor University, Tehran, Iran \\ ${ }^{3}$ Department of Animal Sciences, Islamic Azad University, Abhar Branch, Abhar, Iran
}

\begin{abstract}
Article info
Received 20.01.2020

Received in revised form 24.02.2020

Accepted 25.02.2020

Correspondence author

Omid Parvizi

Tel.: 026-34259571-9

E-mail: omidparvizi1353@gmail.com

2020 Parvizi O. et al. This is an open-access article distributed under the terms of the Creative Commons Attribution License, which permits unrestricted use, distribution, and reproduction in any medium, provided the original author and source are credited.

\begin{tabular}{|l|}
\hline$(\mathrm{cc}) \mathrm{Br}$ \\
\hline
\end{tabular}

Contents

1. Introduction

2. Materials and methods ...............................

Abstract

To determine the effect of using thyme and oregano powder supplementation on performance, some immune response and intestinal morphology of broiler chicks a total of 200 one-day-old Cobb 500 male broiler chicks were divided into the four treatments consisting of five replicates of 10 chicks each. The treatments were as control groups with no herbal, antibiotic and probiotic supplementations. control groups + virginiamycine antibiotic, control groups + protexin probiotic, control groups $+2 \%$ of each thyme and oregano powder supplementation and Control groups $+4 \%$ of each thyme and oregano powder supplementation. The performance parameters such as feed intake, body weight gain and feed conversion ratio were measured during the study period. To determine immunity parameters on days $28,0.5 \mathrm{~mL}$ of $10 \%$ sheep red blood cells suspension was administrated to two chicks per each replicate through and at day $31,3 \mathrm{~mL}$ blood samples were collected from left wing. On day 42 , jejunum tissue samples were separated and fixed in (10\%) neutral buffer formalin and were analyzed by autoprocessing apparatus, there after the slide sections were prepared by rotary microtome type (Manubeni, ErmaTokyo, Japan) and the average of villi measurements was reported as a mean for each bird. The result of this study showed that the dietary inclusion of herbals and probiotic had no significant effects on FI and FCR of broiler chicks but higher body weight gain were seen with they received thyme+oregano supplementation. Inclusion of thyme+oregano and probiotic increased humeral immunity in broiler chicks compared to the control $(\mathrm{P} \leq 0.05)$. Additionally heterophil, lymphocyte and their ratio were not influenced by experimental treatments. The villus length, villus width, and crypt depth were increased were the birds feed by oregano and thyme powders. In conclusion in current study some of beneficial acts toward using thyme and oregano powders on performance, some immune parameters and intestinal morphology on broiler chicks were demonstrated.
\end{abstract}

3. Results and discussion

4. Conclusions

References

Key words: Broiler, Thyme, Oregano, Growth, Immune responses, Intestinal morphology.

\section{Citation:}

Parvizi, O., Taherkhani, R., \& Abouzari, M. (2020). Evaluation the effect of using thyme and oregano powder in comparison to the antibiotic and probiotic supplementation on growth, some immune responses and intestinal morphology of broiler chicks. Ukrainian Journal of Veterinary and Agricultural Sciences, 3(1), 3-8.

\section{Introduction}

The use of antibiotics has banned as growth promoter in animal breeding industry, because of the potential health risks (Simitzis, 2017). The industry is searching to find the appropriate alternative for antibiotics. Some probiotics have been commercially applied to supply the requirements (Bai et al., 2017). Probiotics have been used to develop and stabilize the intestinal flora (Gaggì et al., 2010; Jahromi et al., 2016). Probiotics have been reported to have beneficial effects on growth performance (Gaggì et al., 2010) and immune system in broiler chickens (Seidavi et al., 2017). Probiotics not only improve the antioxidant levels in body, but also improve the healthiness in broilers (Tabidi et al., 2013). It has been suggested the plant derivates, such as plant essential oils and extracts, as alternatives for antibiot- ics in order to improve the productive performance in poultry (Simitzis \& Deligeorgis, 2011). Essential oils consist of low molecular weight aliphatic hydrocarbons such as phenols, aromatic aldehydes (Dorman \& Deans, 2000). EOs is volatile secondary metabolite which has been broadly applied in the cosmetic and food industry. EOs has been also known to have antioxidant properties which could optimize the antioxidant levels in the feed (Simitzis, 2017). Thyme (Thyme vulgaris L.) is a medicinal herb which has medical applications and grows in all the Mediterranean regions. Thyme oils known as a dominant compound in thyme essential oil (Sengul et al., 2008). Beneficial effects of thyme oils on growth performance and immune response of laying hens have recently reported (Attia et al., 2017). Oregano (Origanum vulgare) is extensively found in the entire Mediterranean region. Oregano essential oil has been known to have 
main phenols such as carvacrol (Mathlouthiet al., 2012). Oral supplementation of oregano essential oil improved growth performance as well as humoral and innate immune responses in broiler chicks (Galal et al., 2016). It was hypothesized that loading the mixture of thyme and oregano may efficiently improve growth performance and immune responses of broilers. Thus, the present study was conducted to evaluate the effects of adding microcapsules containing the mixture of thyme and oregano into broiler diet on growth performance, intestinal morphology and immune responses.

\section{Materials and methods}

\section{Birds, Diets and managements}

A total of 200 one-day-old Cobb 500 male broiler chicks were weighed and randomly divided into 20 cages. Chicks were randomly allocated into four treatments consisting of five replicates of 10 chicks each. The treatments were as control groups with no herbal, antibiotic and probiotic supplementations. control groups + virginiamycine antibiotic, control groups + protexin probiotic, control groups $+2 \%$ of each thyme and oregano powder supplementation and control groups $+4 \%$ of each thyme and oregano powder supplementation.

\section{Table 1}

The experimental diet used in starter, grower and finisher period of chicks

\begin{tabular}{|c|c|c|c|}
\hline Ingredient & $\begin{array}{c}\text { Starter } \\
(0-10 d)\end{array}$ & $\begin{array}{c}\text { Grower } \\
(11-24 d)\end{array}$ & $\begin{array}{l}\text { Finisher } \\
(25-42 d)\end{array}$ \\
\hline Corn grain & 51.86 & 58.23 & 62.24 \\
\hline Soybean meal & 38.35 & 29.10 & 30.95 \\
\hline Soybean Oil & 3.53 & 4.26 & 3.22 \\
\hline Fish meal & 2.11 & 5.00 & 0.00 \\
\hline DCP & 0.90 & 1.23 & 0.93 \\
\hline Limestone & 1.80 & 0.97 & 1.43 \\
\hline $\mathrm{NaCl}$ & 0.25 & 0.25 & 0.30 \\
\hline $\begin{array}{l}\text { Vitamin and Mineral } \\
\text { premix }^{*}\end{array}$ & 0.50 & 0.50 & 0.50 \\
\hline DL-Methionine & 0.35 & 0.31 & 0.25 \\
\hline L-Lysine & 0.25 & 0.15 & 0.14 \\
\hline L-Threonine & 0.10 & 0.00 & 0.04 \\
\hline $\begin{array}{l}\text { Analyzed composi- } \\
\text { tion }\end{array}$ & & & \\
\hline Energy (ME), MJ/kg & 12.65 & 13.20 & 13.40 \\
\hline Crude Protein, $\%$ & 23.12 & 21.30 & 19.35 \\
\hline Calcium, $\%$ & 1.05 & 0.90 & 0.85 \\
\hline Av. Phosphorus, \% & 0.50 & 0.45 & 0.42 \\
\hline Lysine, $\%$ & 1.44 & 1.24 & 1.09 \\
\hline Threonine, $\%$ & 0.94 & 0.83 & 0.72 \\
\hline Met+Cys, \% & 1.07 & 0.95 & 0.86 \\
\hline
\end{tabular}

*and**Vitamin \& mineral premix supplied (content per $\mathrm{kg}$ ): vitamin A, 1,800,000 IU; vitamin $\mathrm{D}_{3}, 400,000 \mathrm{IU}$; vitamin $\mathrm{E}$, 3,600 IU; vitamin $\mathrm{K}_{3}, 400 \mathrm{mg}$; thiamine, $360 \mathrm{mg}$; riboflavin, $1,320 \mathrm{mg}$; niacin, 6,000 mg; vitamin $\mathrm{B}_{6}, 600 \mathrm{mg}$; vitamin $\mathrm{B}_{5}$, 2,000; vitamin $\mathrm{B}_{12}, 3 \mathrm{mg}$; folic acid, $200 \mathrm{mg}$; biotin, $20 \mathrm{mg}$, choline, $80 \mathrm{~g}$; zinc, $17 \mathrm{~g}$; iron, $10 \mathrm{~g}$; copper, $2 \mathrm{~g}$; manganese, $20 \mathrm{~g}$; selenium, $40 \mathrm{mg}$; iodine, $200 \mathrm{mg}$.

In addition the birds had adlibitum access to water and feed. The temperature for rearing room was kept at $34 \pm 5{ }^{\circ} \mathrm{C}$ during the first week of the study and then reduced to $22.0{ }^{\circ} \mathrm{C}$ by the end of the third week and was kept until the end of the trial. In this trial thyme and oregano extracts were used. The content of the extracts were as bellows: Thymol (49.70\%), $\gamma$-Terpinen (19.55\%), $\rho$-Cymene (11.82\%), Carvacrol (4.12\%), $\alpha$-Terpinene (4.11\%), Myrcene $(3.64 \%)$, $\alpha$-Pinene $(3.16 \%)$, Limonene $(1.73 \%)$ and Linalool $(2.92 \%)$ were the main compounds in thyme powder. Based on obtained information, carvacrol (63.11\%), $\rho$ Cymene (10.72\%), Linalool (3.42\%) and $\alpha$-terpineol (1.73) were main compounds in oregano powder. Protexin ${ }^{\circledR}$ probiotic contained the Lactobacillus ruteri, Lactobacillus salivarius and Pediococcu ssp. The basal diet was prepared as recommended by Cobb 500 catalogue to satisfy the broilers' requirements. The feed samples were taken and their chemical- nutritional properties were investigated based on AOAC (2004) (Table 1).

\section{Performance}

The broilers were weighed at 1, 12, 24 and end of the 42 days of age, and body weight gain (BWG; g/bird) per replicate was calculated. Feed intake (FI) was calculated for each replicate ( $\mathrm{g} / \mathrm{bird})$ as well as feed conversion ratio (FCR, $\mathrm{g}$ $\mathrm{feed} / \mathrm{g}$ gain) was calculated. Mortality was considered when calculating the growth performance.

\section{Immunity}

On days $28,0.5 \mathrm{~mL}$ of $10 \%$ sheep red blood cells (SRBC) suspension was administrated to two chicks/per replicate through the right wing vein. On day $31,3 \mathrm{~mL}$ blood samples were collected from left wing venipuncture. The samples were incubated at $37^{\circ} \mathrm{C}$ and then centrifuged at $1,500 \times \mathrm{g}$ for $10 \mathrm{~min}$. The sera were collected and stored at $20{ }^{\circ} \mathrm{C}$ until assay for assessment of the primary antibody response to SRBC. Seven days after the first challenge (on days 35), birds were blood taken. Serum samples were evaluated for total antibody response including immunoglobulin (Ig) $\mathrm{G}$ and $\mathrm{M}$ by the 2-mercaptoethanol (ME) procedure as explained previously by Lepage et al. (1996). The measured antibody titers against SRBC were expressed as the $\log _{2}$ of the reciprocal of the highest serum dilution giving complete agglutination. On days 35, the differential counts of heterophils and lymphocytes were measured using two birds per replicate cages as explained by Gross and Siegel (1983).

\section{Cellular immunity}

For evaluating skin hyper sensitivity reaction, one area, by $10 \mathrm{~cm}^{2}$, was marked for Dinitrochlorobenzene application, at 32 days of age. Before sensitization, skin thickness was evaluated. The birds were sensitized with Dinitrochlorobenzene at a dose of $0.25 \mathrm{~mL}$ per $\mathrm{cm}^{2}$ area. After two weeks, the birds were challenged with $0.25 \mathrm{~mL}$ Dinitrochlorobenzene and their skin thickness, three parts in this area, was measured 24 and 48 hours after the challenging dose. Also, $0.01 \mathrm{~mL}$ Phytohemagglutinin (PHA: $10 \mathrm{mg} \cdot \mathrm{mL}^{-1}$ acetone and olive oil in 4:1 ratio) was intradermal injected between the third and fourth digits of the right foot and the area thickness was measured 24 and 48 hours after injection.

\section{Intestinal morphology}

On day 42 , tissue jejunum samples of broiler chickens were separated and fixed in (10\%) neutral buffer formalin. The tissue samples were analyzed by auto-processing apparatus, there after the slide sections were prepared by rotary microtome type (Manubeni, Erma-Tokyo, Japan). The prepared slides $(\mathrm{n}=5)$ from each jejunal segment each broiler 
chicks, and five well oriented villi were measured from each the prepared slide. The average of villi measurements was reported as a mean for each bird. Villus width (VW) was assessed at the base of each villus; villus length (VL) was evaluated from the top of the villus to the villus-crypt junction, and crypt depth (CD) was evaluated from the base of the villus to the sub-mucosa.

\section{Statistical analyses}

After data collection, the ANOVA procedure of SAS (2001) software were used to evaluate the studied parameters and data were compared by Duncan (1995) multiple range test, if were significant.

\section{Results and discussion}

\section{Results}

The results of treatments on growth performance in experimental broilers are shown in table 1. Results showed that dietary inclusion of herbals and probiotic had no significant effects on FI and FCR of broiler chicks. Birds fed with probiotic plus thyme+oregano $2 \%$ had significantly higher BWG compared with those received thyme+oregano and control group on day 24 and 42.

Table 2

The effects of treatments on growth performance

\begin{tabular}{|c|c|c|c|c|c|c|c|c|c|}
\hline Treatments & control & Antibiotic & $\begin{array}{c}\text { Thyme+ } \\
\text { Oregano } \\
2 \%\end{array}$ & $\begin{array}{c}\text { Thyme }+ \\
\text { Oregano } \\
4 \%\end{array}$ & Probiotic & $\begin{array}{c}\text { Probiotic } \\
\text { Thyme+ } \\
\text { Oregano } 2 \%\end{array}$ & $\begin{array}{c}\text { Probiotic } \\
\text { Thyme+ } \\
\text { Oregano4\% }\end{array}$ & SEM & $\begin{array}{c}\text { P- } \\
\text { value }\end{array}$ \\
\hline \multicolumn{10}{|c|}{ Body weight (gr) } \\
\hline 0 & 44.84 & 44.62 & 44.68 & 45.12 & 44.76 & 45.04 & 44.92 & 0.11 & 0.150 \\
\hline 10 & 201.98 & 207.45 & 204.93 & 200.30 & 202.48 & 198.10 & 198.81 & 1.04 & 0.240 \\
\hline 24 & $780.16^{\mathrm{ab}}$ & $819.47^{\mathrm{a}}$ & $824.15^{\mathrm{a}}$ & $761.19^{a b}$ & $788.40^{\mathrm{abc}}$ & $752.87^{\mathrm{c}}$ & $791.37^{\mathrm{bc}}$ & 5.17 & 0.000 \\
\hline 42 & $2247.04^{\mathrm{ab}}$ & $2366.00^{\mathrm{a}}$ & $2377.44^{\mathrm{a}}$ & $2214.25^{\mathrm{b}}$ & $2308.20^{\mathrm{ab}}$ & $2277.30^{\mathrm{ab}}$ & $2392.80^{\mathrm{a}}$ & 18.22 & 0.046 \\
\hline \multicolumn{10}{|c|}{ Feed intake (gr) } \\
\hline $0-10$ & 223.04 & 209.03 & 220.12 & 200.00 & 209.48 & 207.70 & 201.30 & 2.63 & 0.15 \\
\hline $11-24$ & 782.32 & 768.60 & 834.13 & 709.95 & 823.13 & 697.18 & 761.53 & 14.32 & 0.075 \\
\hline $24-42$ & $2693.89^{\mathrm{ab}}$ & $2977.84^{\mathrm{a}}$ & $2692.17^{\mathrm{ab}}$ & $2589.79^{\mathrm{ab}}$ & $2558.43^{b}$ & $2644.27^{b}$ & $2773.88^{\mathrm{b}}$ & 43.72 & 0.068 \\
\hline $0-42$ & $3699.26^{\mathrm{ab}}$ & $3955.47^{\mathrm{a}}$ & $3744.40^{\mathrm{ab}}$ & $3499.75^{\mathrm{ab}}$ & $3591.04^{\mathrm{b}}$ & $3549.16^{\mathrm{b}}$ & $3736.69 b$ & 37.09 & 0.089 \\
\hline \multicolumn{10}{|c|}{ Body weight gain (gr/period) } \\
\hline $1-10$ & 157.14 & 163.13 & 160.24 & 155.18 & 158.72 & 153.06 & 154.89 & 1.09 & 0.190 \\
\hline $11-24$ & 578.19 & 612.03 & 619.21 & 560.88 & 585.92 & 554.76 & 590.55 & 4.94 & 0.001 \\
\hline $25-42$ & 1466.87 & 1546.53 & 1553.29 & 1453.06 & 1519.92 & 1524.43 & 1601.46 & 17.38 & 0.224 \\
\hline $1-42$ & $2202.20^{\mathrm{ab}}$ & $2321.68^{a}$ & $2332.75^{\mathrm{a}}$ & $2169.13^{\mathrm{b}}$ & $2264.56^{\mathrm{ab}}$ & $2232.26^{\mathrm{ab}}$ & $2347.91^{\mathrm{a}}$ & 18.24 & 0.046 \\
\hline \multicolumn{10}{|c|}{ FCR } \\
\hline $0-10$ & 1.416 & 1.278 & 1.377 & 1.295 & 1.320 & 1.357 & 1.300 & 0.015 & 0.110 \\
\hline $11-24$ & 1.343 & 1.259 & 1.346 & 1.269 & 1.400 & 1.262 & 1.288 & 0.020 & 0.430 \\
\hline $25-42$ & 1.846 & 1.907 & 1.740 & 1.812 & 1.685 & 1.742 & 1.733 & 0.020 & 0.116 \\
\hline $1-42$ & 1.679 & 1.693 & 1.610 & 1.620 & 1.580 & 1.590 & 1.590 & 0.014 & 0.201 \\
\hline
\end{tabular}

SEM: Standard error of means. Superscripts (a-c) show significant differences per column $(\mathrm{P}<0.05) . \mathrm{FI}=$ Feed intake, $\mathrm{BWG}=\mathrm{Body}$ weight gain, $\mathrm{FCR}=$ Feed conversion ratio

\section{Immunity}

The result of treatments on some humeral immunity parameters of broiler chicks this study showed that dietary inclusion of thyme+oregano and probiotic increased hu- meral immunity in broiler chicks compared to the control $(\mathrm{P}<0.05)$. Additionally heterophil, lymphocyte and their ratio were not influenced by experimental treatments $(\mathrm{P}>0.05)$.

Table 3

The effects of treatments on some humeral immunity parameters of broiler chicks

\begin{tabular}{cccccccc}
\hline Groups & $\operatorname{IgG}_{1}$ & $\operatorname{IgM}_{1}$ & $\operatorname{IgG}_{2}$ & $\operatorname{IgM}_{2}$ & Heterophil & Lymphocyte & $\mathrm{H} / \mathrm{L}$ \\
\hline Control & $1.73^{\mathrm{c}}$ & $2.50^{\mathrm{b}}$ & $2.51^{\mathrm{b}}$ & $2.26^{\mathrm{b}}$ & 17.90 & 77.70 & 0.23 \\
Antibiotic & $1.63^{\mathrm{c}}$ & $2.49^{\mathrm{b}}$ & $2.47^{\mathrm{b}}$ & $2.35^{\mathrm{b}}$ & 18.00 & 80.10 & 0.22 \\
Thyme +Oregano 2\% & $1.96^{\mathrm{b}}$ & $3.22^{\mathrm{a}}$ & $3.05^{\mathrm{a}}$ & $2.77^{\mathrm{a}}$ & 17.10 & 79.60 & 0.22 \\
Thyme +Oregano 4\% & $1.67^{\mathrm{c}}$ & $2.77^{\mathrm{b}}$ & $2.58^{\mathrm{b}}$ & $2.21^{\mathrm{b}}$ & 16.40 & 78.00 & 0.23 \\
Probiotic & $1.73^{\mathrm{c}}$ & $2.59^{\mathrm{b}}$ & $2.48^{\mathrm{b}}$ & $2.24^{\mathrm{b}}$ & 16.60 & 76.40 & 0.23 \\
Probiotic+ Thyme +Oregano 2\% & $2.03^{\mathrm{b}}$ & $3.08^{\mathrm{a}}$ & $3.18^{\mathrm{a}}$ & $2.81^{\mathrm{a}}$ & 16.00 & 78.00 & 0.22 \\
Probiotic Thyme +Oregano 4\% & $2.19^{\mathrm{a}}$ & $3.03^{\mathrm{a}}$ & $3.32^{\mathrm{a}}$ & $2.84^{\mathrm{a}}$ & 16.40 & 76.40 & 0.23 \\
SEM & 0.12 & 0.15 & 0.24 & 0.15 & 0.37 & 1.07 & 0.013 \\
P-value & 0.001 & 0.001 & 0.001 & 0.001 & 0.61 & 0.102 & 0.091 \\
\hline
\end{tabular}

SEM: Standard error of means. Superscripts $(\mathrm{a}-\mathrm{d})$ show significant differences per column $(\mathrm{P}<0.05)$ 


\section{Intestinal morphology}

The effects of treatments on villus length (VL), villus width (VW), and crypt depth (CD) $(\mu \mathrm{m})$ are shown in table 5. Data from this study also showed that dietary inclusion of oregano $4 \%$ significantly increased $\mathrm{VW}, \mathrm{VL}$ and $\mathrm{CD}$ in comparison to other groups $(\mathrm{P}<0.05)$.

\section{Table 5}

The effects of treatments on villus length (VL), villus width (VW), and crypt depth (CD) $(\mu \mathrm{m})$

\begin{tabular}{cccc}
\hline Groups & VL & VW & CD \\
\hline Control & $1489.00^{\mathrm{b}}$ & $185.00^{\mathrm{b}}$ & $145.30^{\mathrm{b}}$ \\
Antibiotic & $1467.00^{\mathrm{b}}$ & $181.30^{\mathrm{b}}$ & $145.80^{\mathrm{b}}$ \\
Thyme +Oregano 2\% & $1767.00^{\mathrm{a}}$ & $204.60^{\mathrm{a}}$ & $183.80^{\mathrm{a}}$ \\
Thyme +Oregano 4\% & $1457.00^{\mathrm{b}}$ & $182.80^{\mathrm{b}}$ & $145.20^{\mathrm{a}}$ \\
Probiotic & $1458.00^{\mathrm{b}}$ & $183.50^{\mathrm{b}}$ & $144.60^{\mathrm{b}}$ \\
Probiotic+ Thyme & $1434.00^{\mathrm{b}}$ & $183.00^{\mathrm{b}}$ & $144.40^{\mathrm{b}}$ \\
+Oregano 2\% & & & \\
Probiotic Thyme & $1775.00^{\mathrm{a}}$ & $205.80^{\mathrm{a}}$ & $188.70^{\mathrm{a}}$ \\
+Oregano 4\% & & & \\
SEM & 87.56 & 5.24 & 8.12 \\
P-value & 0.001 & 0.001 & 0.001 \\
\hline
\end{tabular}

SEM: Standard error of means. Superscripts (a-b) show significant differences per column $(\mathrm{P}<0.05)$.

\section{Discussion}

According to our data the averages means showed that the dietary inclusion of oregano and probiotic had not significant effects on FI and FCR. Pournazari et al. (2017) have reported that dietary inclusion of thyme and probiotic, singly form, increased FI but only dietary inclusion of probiotic decreased BWG in broiler chicks. It has been reported that oral supplementation of oregano did not improve FI and FCR in broiler chicks (Galal et al., 2016). It seems that oregano $4 \%$ cannot improve the FI and FCR in broiler chicks. Increase the oregano levels could increase BWG in comparison with others form on day 24 and 42; suggested that increaseof herbal levels may efficiently increase BWG. Also unsing of oregano at $4 \%$ levels also caused to increase the BWG compared with control group. It was no observed significant differences among thyme+oregano $2 \%$ compared with control group. Ragga et al. (2016) showed that dietary inclusion of thyme could increase BWG in broiler chicks. Increased BWG can be attributed to antioxidant properties and phenolic properties of oregano which decreases harmful effects of bacteria on intestinal system and help to more absorption amino acids (Lee et al., 2004). Oreganos compounds not only help more absorption amino acids but also promote more digestive enzymes secretion which subsequently increase nutrient absorption for more growth (Lee et al., 2004). In addition, intestinal morphology was significantly improved in the encapsulated group which can confirm improved BWG by increasing nutrient absorption. The intestinal villi is known to have essential roles in promoting nutrient digestion and absorption, because villi greatly enhance small intestine surface area and are known as initial tissues in the intestine which cause to contact with nutrients (Gartner \& Hiatt, 2001). Dietary inclusion of probiotic could not improve the growth performance compared with control group. Pournazari et al. (2017) reported that dietary inclusion of thyme and probiotic increased BWG. It has been reported that probiotics improve broiler performance by increasing the immune modulation capacity of broilers (Yang et al., 2012). The conflictions between our findings and others can be due to strains of probiotics, dosage, procedures of preparation, bird age, diet compounds and hygiene conditions (Zhang et al., 2012). The SR and PEI were also better in higher levels of herbal using groups which implicates on better efficiency of their compounds.

In this study thyme+ oregano and probiotic at $2 \%$ levels had better humoral immunity in comparison with other groups. Hashemipour et al. (2013) have reported that dietary inclusion of thymol+carvacrol increased the cellular and humoral immune responses in broilers. Flavonoids and other phenolic components, present in essential oils, increases activity of vitamin $\mathrm{C}$ as immune stimulator (Manach et al. 1996). Amresh et al. (2007) have also reported flavonoids and polyphenolic compounds help immune system by their antioxidant activity. A combination of oregano and probiotic improved humoral immunity; showing synergism interaction effects between oregano and probiotic. Probiotics have been known to have immune modulatory activities in birds ( $\mathrm{Pa}-$ turi et al., 2007). Probiotics improve the immune system by modulating in intestinal system. Thus, a combination of oregano and probiotic can improve immune system. Heterophil, lymphocyte and their ratio were not influenced by experimental treatments which was similar those reported by Attia et al., (2017).

The usage of oregano powder at level $4 \%$ could improve intestinal morphology compared other groups. The VL and $\mathrm{CD}$ are known as good indicator for intestinal health and digestive tract maintenance (Pluske et al., 1996). It has been accepted the role of some nutrients as promoter the morphological development of the small intestine (Kadam et al., 2009; Yadav et al., 2010). Several in vivo studies have reported the role of oregano as promoter for growth the intestine (Yadav et al., 2010; Amad et al., 2013). The improved intestinal morphology can be attributed to alleviating effects of oregano on toxins. Bacterial toxins are known to have negative effects on intestinal morphology (Samadian et al., 2013). It has been reported that oregano reduces production of toxic compounds and damage to intestinal epithelial cells of broiler chicks (Yakhkeshi et al., 2011; Samadian et al., 2013). With regards to probiotics, it has been shown positive role of probiotics in increasing the villus length (Awad et al., 2009; Tsirtsikos et al., 2012).

\section{Conclusions}

In the current study some of beneficial acts toward using thyme and oregano powders on performance, some immune parameters and intestinal morphology on broiler chicks were demonstrated. We also could conclude that it will be possible that the higher concentration of these herbal may produce better result in term of weight of studied parameters in broilers chicks. This improvement may be due to the biological functions to improve growth, digestibility and other activities that found in thyme and oregano compounds. Although the beneficial effects on health and growth are believed to be mediated by effects on gastrointestinal macrobiotic, the underlying mechanisms remain to be discovered. Also further researches are needed on the other microbial and other biochemical parameters and other studies are needed to more detail explanation. 


\section{References}

Amad, A. A., Wendler, K. R., \& Zentek, J. (2013). Effects of a phytogenic feed additive on growth performance, selected blood criteria and jejunal morphology in broiler chickens. Emirates Journal of Food Agriculture, 25(7), 549-554. doi: 10.9755/ejfa.v25i7.12364.

Amresh, G., Reddy, G., Rao, C. V., \& Singh, P., (2007). Evaluation of anti-inflammatory activity of Cissampelospareira root in rats. Journal of Ethnopharmacology, 110(3), 526-531. doi: 10.1016/j.jep.2006.10.009.

AOAC. (2004). Official methods of analysis. 18th ed. Washington, DC: AOAC.

Attia, Y. A., Bakhashwain, A. A., \& Bertu, N. K. (2017). Thyme oil (Thyme vulgaris L.) as a natural growth promoter for broiler chickens reared under hot climate. Italian Journal of Animal Science, 16(2), 275-282. doi: 10.1080/1828051X.2016.1245594.

Awad, W. A., Ghareeb, K., Abdel-Raheem, S., \& Bohm, J., (2009). Effects of dietary inclusion of probiotic and synbi-otic on growth performance, organ weights, and intestinal histomorphology of broiler chickens. Poultry Science, 88(1), 49-56. doi: 10.3382/ps.2008-00244.

Bai, K., Huang, Q., Zhang, J., He, J., Zhang, L., \& Wang, T., (2017). Supplemental effects of probiotic Bacillus subtilis fmbJ on growth performance, antioxidant capacity, and meat quality of broiler chickens. Poultry Science, 96(1), 1-9. doi: $10.3382 / \mathrm{ps} /$ pew 246 .

Bilia, A. R., Guccione, C., Isacchi, B., Righeschi, C., Firenzuoli, F., \& Bergonzi, M. C. (2014). Essential oils loaded in nanosystems: A developing strategy for a successful therapeutic approach. Evidences Based Complement Alternative Medicine, 2014, 651593. doi: 10.1155/2014/651593.

Dorman, H. J. D., \& Deans, S. G., (2000). Antimicrobial agents from plants: Antibacterial activity of plant volatile oils. Journal of Applied Microbiology, 88(2), 308-316. doi: 10.1046/j.13652672.2000.00969.x.

Gaggìa, F., Mattarelli, P., \& Biavati, B., (2010). Probiotics and prebiotics in animal feeding for safe food production. International Journal of Food Microbiology, 141(1), S15-S28. doi: 10.1016/j.ijfoodmicro.2010.02.031.

Galal, A. A. A., El-Araby, I. E., Hassanin, O., \& Omar, A. E. (2016). Positive impact of oregano essential oil on growth performance, humoral immune responses and chicken interferon alpha signalling pathway in broilers. Advance Animal Veterinary Science, 4(1), 57-65. doi: 10.14737/journal.aavs/2016/4.1.57.65.

Gartner, L. P., \& Hiatt, J. L. (2001). Color Textbook of Histology.2nd ed. W. B. Saunders, Baltimore, MD.

Gross, W. B., \& Siegel, H. S. (1983). Evaluation of the heterophil to lymphocyte ratio as a measure of stress in chickens. Avian Diseases, 27(4), 972-979. https://www.jstor.org/stable/pdf/ 1590198.pdf?seq=1.

Hashemipour, H., Kermanshahi, H., Golian, A., \& Veldkamp, T. (2013). Effect of thymol and carvacrol feed supplementation on performance, antioxidant enzyme activities, fatty acid composition, digestive enzyme activities, and immune response in broiler chickens. Poultry Science, 92(8), 2059-2069. doi: $10.3382 /$ ps.2012-02685.

Jahromi, M. F., Altaher, Y. W., Shokryazdan, P., Ebrahimi, R., Ebrahimi, M., Idrus, Z., Goh, Y. M., Tufarelli, V., \& Liang, J. B. (2016). Dietary supplementation of a mixture of lactobacillus strains enhances performance of broiler chickens raised under heat stress conditions. International Journal of Biometeorology, 60(7), 1099-1110. doi: 10.1007/s00484-0151103-x.

Kadam, A. S., Nikam, M. G., Patodkar, V. R., Muglikar, D. M., Lonkar, V. D., Yadav, G. B., Maini, S., Ravikanth, K., \& Meshram, M. D. (2009). Influence of herbal early chick nutritional supplement on the growth performance,serumbiochemicals and immune response of broiler chicken. International Journal of Poultry Science, 8(4), 349-354. doi: 10.3923/ijps.2009.349.354.

Kotronia, M., Kavetsou, E., Loupassaki, S., Kikionis, S., Vouyiouka, S., \& Detsi, A. (2017). Encapsulation of oregano (Origanum onites L.) essential oil in $\beta$-Cyclodextrin $(\beta-C D)$ : Synthesis and characterization of the inclusion complexes. Bioengineering, 4(3), 74. doi: 10.3390/bioengineering4030074.

Lee, K. W., Everts, H., \& Kappert, H. J. (2004). Growth performance, intestinal viscosity, fat digestibility and plasma cholesterol in broiler chicks. International Journal of Poultry Science, 3(9), 613-618. doi: 10.3923/ijps.2004.613.618.

Lepage, K. T., Bloom, S. E., \& Taylor, R. L. (1996). Antibody response to sheep red blood cells in a major histocompatibility (B) complex aneuploid line of chickens. Poultry Science, 75, 346-350.

Manach, F., Regerat, F., \& Texier, O., (1996). Bioavailability, metabolism and physiological impact of 4-oxo-flavonoids. Neutral Research, 16(3), 517-544. doi: 10.1016/02715317(96)00032-2.

Mathlouthi, N., Bouzaienne, T., Oueslati, I., Recoquillay, F., Hamdi, M., Urdaci, M., \& Bergaoui, R., (2012). Use of rosemary, oregano, and a commercial blend of essential oils in broiler chickens:In vitro antimicrobial activities and effects on growthperformance. Journal of Animal Science, 90(3), 813823. doi: $10.2527 /$ jas.2010-3646.

Paturi, G., Phillips, M. Jones, M., \& Kailasapathy, K. (2007). Immune enhancing effects of Lactobacillus acidophilus, lafti 110 and Lactobacillus paracasei, lafti 126 in mice. International Journal of Food Microbiology, 115(1), 115-118. doi: 10.1016/j.ijfoodmicro.2006.10.007.

Pluske, J. R., Thompson, M. J., Atwood, C. S., Bird, P. H., Williams, L. H., \& Hartmenn, P. E. (1996). Maintenance of villus height and crypt depth, and enhancement of di-saccharide digestion and monosaccharide absorption, in piglets fed on cows' whole milk after weaning. British Journal of Nutrition, 76(3), 409-422. doi: 10.1079/bjn19960046.

Pournazari, M., Qotbi, A.A.A., Seidavi, A.R., Corazzin, M., (2017). Prebiotics, probiotics and thyme (Thymus vulgaris) for broilers:performance, carcass traits and blood variables. Review Colombia CiencPecu, 30, 3-10. doi: 10.17533/udea.rccp. v30n1a01.

Ragga, N. M. Kornay, R. S., \& Mohamad, F. (2016). Effects of thyme/or formic acid dietary supplementation on broiler performance and immunity. Agriculture and Agricultural Science Procedia, 10, 270-279. doi: 10.1016/j.aaspro.2016.09.064.

Ross. Ross 308 Broiler (2014). Nutrition specification manual. Midhlotian (UK): Aviagen Ltd.

Samadian, F., Saeed, Z., Armin, T., Mohammad, A. K. T., Zarbakht, A. P., \& Pedram, G. (2013). Evaluation of some phytogenic feed additives in growingchicks diet. International Journal of Agriculture Research Review, 3, 35-43.

Seidavi, A., Dadashbeiki, M., Alimohammadi-Saraei, M., van den Hoven, R., Payan-Carreira, R., Laudadio, V., \& Tufarelli, V. (2017). Effects of dietary inclusion level of a mixture of probiotic cultures and enzymes on broiler chickens immunity response. Environment Science Pollutant Research, 24, 46374644. doi: 10.1007/s11356-016-8206-8.

Sengul, T., Yurtseven, S., Cetin, M., Kocyigit, A., \& Sogut, B. (2008). Effect of thyme T. vulgaris extracts on fattening performance, some blood parameters, oxidative stress and DNA damage in Japanese quail. Journal of Animal Feed Science, 17(4), 608-620. doi: 10.22358/jafs/66689/2008.

Simitzis, P. E., \& Deligeorgis, S. G. (2011). The effects of natural antioxidants dietary supplementation on the properties of farm animal products. In Animal Feed: Types, Nutrition, Safety; Nova Science Publishers, Inc.: New York, NY, USA, 155-168.

Simitzis, P. E. (2017). Enrichment of animal diets with essential oils-a great perspective on improving animal performance and quality characteristics of the derived products. Medicines, 4(2), 35-45. doi: 10.3390/medicines4020035. 
Stoica, R., Somoghi, R., \& Ion, R. M., (2013). Preparation of chitosan- tripolyphosphatenanoparticles for the encapsulation of polyphenols extracted form rose hips. Journal of Nano Biostructre, 8(3), 955-963. http://chalcogen.ro/955_Stoica.pdf.

Tabidi, M. H., Mukhtar, A. M., \& Mohammed. H. I. (2013). Effectsof probiotic and antibiotic on performance and growth attributes of broiler chicks. Global Journal of Medicinal Plant Research, 1, 136-142.

Tsirtsikos, P., Fegeros, K., Balaskas, C., Kominakis, A., \& Mountzouris, K. C. (2012). Dietary probiotic inclusion level modulates intestinal mucin composition and mucosal morphology in broilers. Poultry Science, 91(8), 1860-1868. doi: 10.3382/ps.2011-02005.

Yadav, G. B., Kadam, A. S., Pachpande, A. M., Lambate, S. B., Lonkar, V. D., Maini, S., \& Ravikanth, K. (2010). Post- hatch histomorphological studies of small intestinal development in chicks fed with herbal early chick nutritional supplement.
International Journal of Poultry Science, 9(9), 851-855. doi: 10.3923/ijps.2010.851.855.

Yakhkeshi, S., Rahimi, S., \& Gharib Naseri, K. (2011). The effects of comparison of herbal extracts, antibiotic, probiotic and organic acid on serum lipids, immune response, GIT microbial population, intestinal morphology and performance of broilers. Journal of Medicinal Plants Research, 10(37), 80-95. http://jmp.ir/article-1-236-fa.pdf.

Yang, C. M., Cao, G. T., Ferket, P. R., Liu, T. T., Zhou, L., Zhang, L., Xiao, Y., \& Chen, A. G. (2012). Effects of probiotic, Clostridiumbutyricum, on growth performance, immune function, and cecal microflora in broiler chickens. Poultry Science, 91(9), 2121-2129. doi: 10.3382/ps.2011-02131.

Zhang, Z. F., Zhou, T. X., Ao, X., \& Kim, I. H. (2012). Effects of $\beta$ - glucan and Bacillus subtilis, on growth performance, blood profiles, relative organ weight and meat quality in broilers fed maize-soybean meal based diets. Livestock Science, 150(1-3), 419-424. doi: 10.1016/j.livsci.2012.10.003. 